\title{
New Xylobanus and related taxa of net-winged beetles from New Guinea (Coleoptera: Lycidae)
}

\author{
Новые виды Xylobanus и родственных ему родов \\ жууков-краснокрымов из Новой Гвинеи (Coleoptera: Lycidae)
}

\author{
Sergey V. Kazantsev \\ С.В. Казанцев
}

Insect Centre, Donetskaya 13-326, Moscow 109651, Russia.

Инсект-центр, ул. Донецкая 13-326, Москва 109651, Россия. E-mail: kazantss@mail.ru

KEY WORDS: Coleoptera, Lycidae, new genus, new species, Papuan region.

КЛЮЧЕВЫЕ СЛОВА: Coleoptera, Lycidae, новый род, новые виды, Папуасская область.

ABSTRACT. A new genus, Xylothrix gen.n., and twelve new species, Xylothrix athrix, X. avicollis, Xylobanus baitetaensis, $X$. pecten, $X$. rotundeareolatus, $X$. telefominensis, $X$. waigeoensis, $X$. culex, $X$. fakfakensis, Xylobanomorphus triton, Malacolycus lacius and Mimoxylobanus nubilus spp.n., are described from New Guinea and adjacent islands. Some taxonomic problems related to Xylobanus and related genera are discussed.

РЕЗЮМЕ. Из Новой Гвинеи и прилегающих островов описывается новый род, Xylothrix gen.n., и двенадцать новых видов, Xylothrix athrix, X. avicollis, Xylobanus baitetaensis, $X$. pecten, $X$. rotundeareolatus, X. telefominensis, X. waigeoensis, X. culex, X. fakfakensis, Xylobanomorphus triton, Malacolycus lacius и Mimoxylobanus nubilus spp.n. Обсуждаются некоторые таксономические вопросы, относящиеся к Xylobanus и близким к нему родам.

\section{Introduction}

The net-winged beetles of New Guinea have a rather long history of study, with the first species described in the first half of the XIX century [Guérin-Méneville, 1833]. However, the first paper devoted entirely to the fauna of the island, with description of several new genera and over a hundred new species was published only in the first half of the XX century by Richard Kleine [1926a]. It was followed by a number of others shortly afterwards [Kleine, 1926b, 1935a, b, 1939] and then after a 50-year pause [Bocák, Bocáková, 1991, 1992; Bocáková, 1997; Bocák, 1997, 1999a, b, 2001; Kazantsev, 2007, 2010].

The number of lycid species and genera in New Guinea is fairly high (and apparently to be further increasing), but diversity of the higher level taxa is not that impressive, with the local net-winged fauna belonging, in fact, by and large, in Metriorrhynchini, with some addi- tions just from Calochromini, Platerotini and Erotini [Kleine, 1933, 1935a, b].

The genus Xylobanus Waterhouse, 1878, a member of Metriorrhynchini and a wide-spread species-rich Old World genus, lists eleven New Guinean species [Kleine, 1933, 1935b]. A few other somewhat similar-looking net-winged beetles are attributed to Mimoxylobanus Pic, 1921, Xylobanomimus Kleine, 1926, Xylobanomorphus Kleine, 1935 and Malacolycus Kleine, 1943. Of these four genera only Xylobanomorphus has recently lost its monotypic and endemic status [Kazantsev, 2010], all the rest are still monotypic and endemic to New Guinea, with Mimoxylobanus and Malacolycus known only from the unique types of their type-species.

The present study, based on examination of New Guinean Lycidae collections from the Institut Royal de Sciences naturelles de Belgique in Bruxelles, the Erfurt Naturkundemuseum, the Entomological Society of Latvia, and the Moscow Insect Centre, allows to describe several new species in Xylobanus and in until now monotypic Mimoxylobanus and Malacolycus, as well as to suggest a new genus to accommodate two of the new species whose attribution to existing genera did not seem possible, and at the same time to address certain taxonomic problems related to Xylobanus and related genera of the region.

\section{Material and Methods}

Several thousand lycid specimens were collected by Dr. Olivier Missa at one site in Madang province, Papua New Guinea, between 1993 and 1996. The collecting methods were light traps (most specimens) and canopy fogging. The collecting site was located in the centre of Baiteta forest $\left(05^{\circ} 01^{\prime} \mathrm{S}, 145^{\circ} 45^{\prime} \mathrm{E}\right), 4 \mathrm{~km}$ inland from the Papua New Guinea northern coast in the Madang province and 50-100 meters above sea level. Baiteta forest is a remnant patch of lowland mixed tropical rainforest with a relatively high canopy of 35-40 m [Riedel, 2008]. 
Other collecting methods (used by members of expeditions of other mentioned institutions) included Malaise traps, ultraviolet, white and mercury-vapor light.

The studied specimens were glued on cardboard plates. For a detailed examination they were relaxed in water; then the detached ultimate abdominal segments were treated for several hours in $10 \% \mathrm{KOH}$ at room temperature, then, with the extracted genitalia, placed in microvials with glycerin; or, glued back on cardboard plates, along with the extracted genitalia, without the $\mathrm{KOH}$ treatment.

MSP-1 zoom stereoscopic dissecting microscope with x8-x80 magnification range was used. Photographs were taken with Canon EOS 6D camera and Canon MP-E 65 mm lens.

The following acronyms are used in the paper: DTC - private collection of Dr. D. Telnov, Riga; ICM - Insect Center, Moscow; IRSN — Institut Royal de Sciences naturelles de Belgique, Bruxelles; NME Naturkundemuseum, Erfurt.

\section{Taxonomy}

Xylobanus Waterhouse, 1879

Xylobanus Waterhouse, 1879: 38

type species: Lycus costifer Walker, 1858: 282 (original designation).

\section{Xylobanus baitetaensis Kazantsev, sp.n.} Figs 1-3

MATERIAL: Holotype, $\sigma^{7}$, Papua New Guinea, Madang prov., Baiteta, light, 13.IV.1996, O. Missa leg. (IRCN); paratypes, 433 $\sigma^{7} \sigma^{7}$ and 197 OP, same label, dates: from 18.III.1993 through 6.IX.1993, 16.IV.1994, 16.IV.1995, 15.VII.1995 and from 18.II.1996 through 27.VII.1996; and $3 \mathrm{O}^{\top} \mathrm{O}^{7}$, Papua New Guinea, Madang prov., Baiteta, canopy fogging, O. Missa leg., dates: 7.VII.1995, 5.IX.1995 and 16.V.1996 (ICM and IRCN).

DESCRIPTION. Male. Dark brown to black; pronotal margins narrowly slightly lighter.

Vertex with two small deep round impressions behind antennal prominence. Eyes relatively large, interocular distance ca. 0.8 eye diameter. Labrum small, transverse, rounded anteriorly and slightly emarginate medially. Palps slender; ultimate maxillary palpomeres small, elongate, almost parallel-sided, flattened and glabrous at truncate apex; ultimate labial palpomeres small, elongate, pointed and glabrous at apex. Antennal sockets narrowly separated. Antennae attaining to elytral middle, from antennomere 3 flabellate; antennomere $3 \mathrm{ca} .7$ times longer than antennomere 2 and subequal in length to antennomere 4; flabella of antennomere 3 ca. 1.25 times longer than same antennomere, flabella of antennomere 4 ca. 1.6 times longer than same antennomere; antennomeres 3-11 with short erect pubescence (Fig. 1).

Pronotum transverse, ca. 1.3 times as wide as long, slightly narrowing anteriorly, bisinuate basally, with small acute posterior and conspicuous blunt anterior angles; median cell narrow, extending to 0.7 pronotal length; anterior

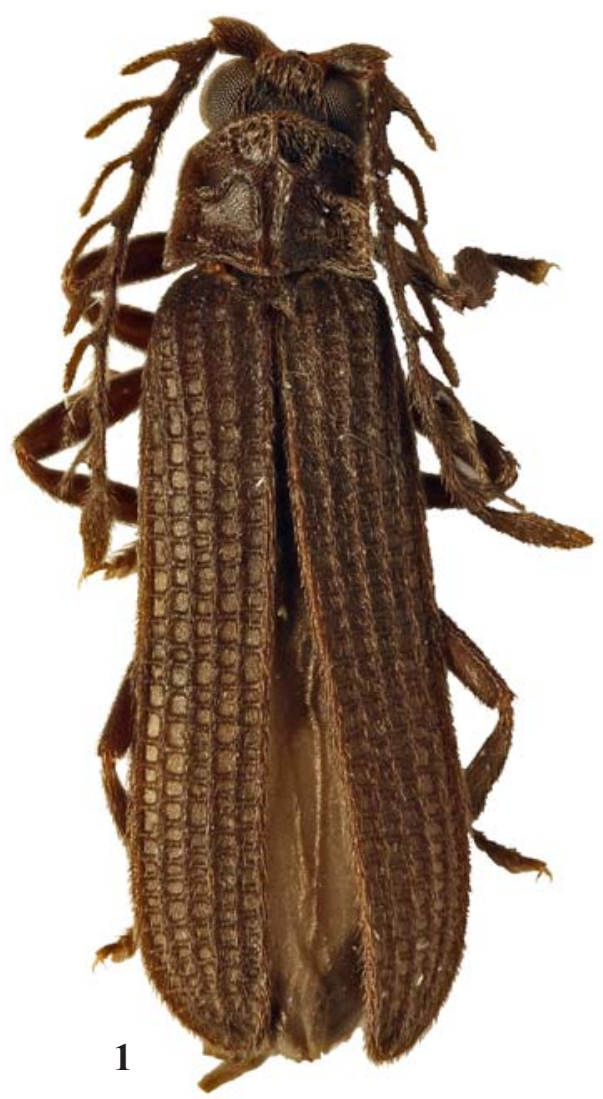

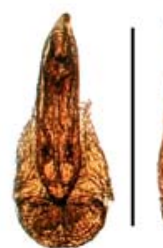

2

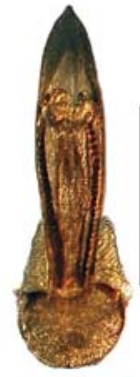

5

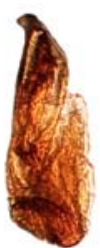

3

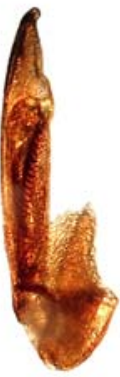

6

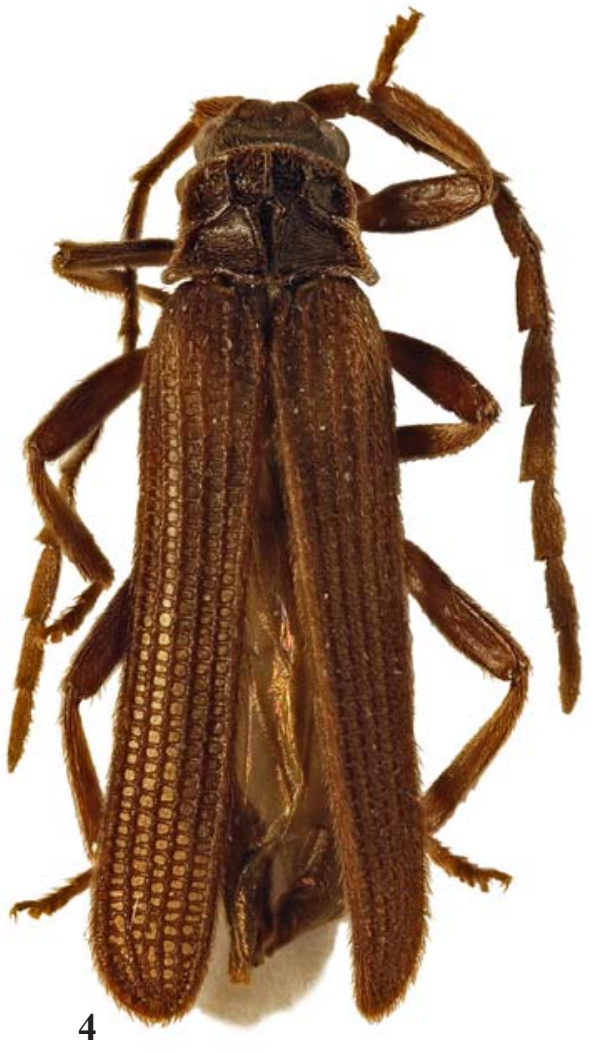

Figs 1-6. General view and aedeagi of Xylobanus, holotypes, males: 1-3-X. baitetaensis sp.n.; 4-6-X. pecten sp.n.; 1, 4 - general view; 2-3, 5-6- aedeagi; $1-2,4-5-$ dorsally; 3,6 - laterally. Scale: $0.5 \mathrm{~mm}$.

Рис. 1-6. Общий вид и эдеагусы Xylobanus, голотипы, самцы: 1-3-X. baitetaensis sp.n.; 4-6-X. pecten sp.n.; 1, 4 - общий вид; 2-3, 5-6 - эдеагусы; 1-2, 4-5 - сверху; 3, 6- сбоку. Масштабная линейка: 0.5 мм. 
cells subquadrate, formed by straight anteriorly carinae. Scutellum subquadrate, parallel-sided, greatly incised at apex (Fig. 2).

Elytra long, 3.3 times longer than wide at humeri, parallel-sided, with equally developed primary costae; interstices with even rows of regular subquadrate cells; bottom of cells velvety and hairless; pubescence along costae short and decumbent (Fig. 1).

Tibiae and femurs straight, flattened and wide; tarsi short, ca. 0.55 length of tibiae.

Aedeagus with slightly widened distally in lateral view and hooked at apex median lobe; inner sac with two pairs of small curved elongate hooks in proximal and distal parts (Figs 2-3).

Female. Similar to male, differing by smaller eyes and just dentate antennae.

Length: 4.7-6.6 mm. Width (humerally): $1.1-1.5 \mathrm{~mm}$.

ETYMOLOGY. The new species is named after "Baiteta", the locality where its type series was collected.

DIAGNOSIS. Xylobanus baitetaensis sp.n. is similar to $X$. monilis Kleine, 1926, but may be differentiated by the longer antennal flabellae, uniformly dark brown to black pronotal disk and considerably broader, especially in the proximal portion, and hooked apically median lobe of the aedeagus (Figs 1-3).

REMARKS. All several hundred specimens of the type series of Xylobanus baitetaensis sp.n. were collected at light, except for three males collected by canopy fogging.

\section{Xylobanus pecten Kazantsev, sp.n.} Figs 4-6

MATERIAL: Holotype, $\sigma^{7}$, Papua New Guinea, $10 \mathrm{~km} \mathrm{~N}$ Madang, 2 km NNW Riwo, 9-11.II.1989, M. \& R. Holyñski leg. (ICM).

DESCRIPTION. Male. Dark brown; maxillary palps, labrum, trochanters and base of femurs light brown.

Vertex with transverse impression behind and median longitudinal impression between antennal prominences. Eyes relatively small, interocular distance ca. 1.7 times greater than eye diameter. Labrum small, roundish, wider than long, slightly emarginate medially. Palps with greatly enlarged ultimate palpomeres. Antennal sockets narrowly separated. Antennae attaining to elytral four fifths, dentate, narrow; antennomere $3 \mathrm{ca} .10$ times longer than antennomere 2 and subequal in length to antennomere 4; antennomeres 3-11 with short erect pubescence (Fig. 1).

Pronotum transverse, ca. 1.5 times as wide as long, with almost parallel sides, bisinuate basally, with prominent acute posterior and noticeable blunt anterior angles; median cell narrow, extending to 0.6 pronotal length; lateral carinae almost straight; anterior cells elongate, formed by straight anteriorly carinae. Scutellum subquadrate, narrowing distally, emarginate at apex (Fig. 4).

Elytra long, ca. 3 times longer than wide at humeri, parallel-sided, with strong equally developed primary costae; interstices with even rows of regular roundish cells; bottom of cells glabrous and hairless; pubescence along costae short and decumbent (Fig. 4)

Tibiae and femurs straight, flattened, relatively narrow; tarsi short, ca. 0.6 length of tibiae.

Aedeagus with straight, narrowed proximally and distally and slightly hooked at apex median lobe; inner sac with a pair of long sclerotised comb-like structures (Figs 5-6).

Female. Unknown.

Length: $5.1 \mathrm{~mm}$. Width (humerally): $1.25 \mathrm{~mm}$.
ETYMOLOGY. The name of the new species is derived from the noun "pecten" (Latin "comb"), alluding to the paired comb-like inner sack structure.

DIAGNOSIS. Xylobanus pecten sp.n. may be differentiated from $X$. neglectus Kleine, 1926 described from one female, by the dark brown to black breast and legs, with trochanters and the very base of femurs light brown. It differs from all other Xylobanus species by the enlarged ultimate maxillary palpomeres and sclerotised comb-like inner sack structures of the aedeagus (Figs 5-6).

\section{Xylobanus rotundeareolatus Kazantsev, sp.n.} Figs 7-9

MATERIAL: Holotype, $\sigma^{7}$, Papua New Guinea, Madang prov., Baiteta, light, 17.VII.1996, O. Missa leg. (IRCN); paratypes, 25 $0^{7} \sigma^{7}$, same label, dates: 23.IV.1993, 23.IV.1993 (2 specimens), 9.IV.1996 (2 specimens), 24.IV.1996, 25.IV.1996, 29.IV.1996 (3 specimens), 30.IV.1996, 1.V.1996, 15.V.1996, 20.V.1996 (3 specimens), 23.V.1996, 6.VI.1996 (2 specimens), 19.VI.1996, 20.VI.1996, 11.VII.1996, 15.VII.1996, 17.VII.1996 (2 specimens), 18.VII.1996, 5 우, same label, dates: 18.II.1996, 23.IV.1996, 25.IV.1996, 29.IV.1996, 14.V.1996, and $0^{7}$, Papua New Guinea, Madang prov., Baiteta, canopy fogging, 27.IV.1995, O. Missa leg. (ICM and IRCN).

DESCRIPTION. Male. Dark brown; broad pronotal sides and ultimate antennomere light brown.

Vertex with two small deep impressions behind antennal prominence. Eyes moderately large, interocular distance ca. 0.9 eye diameter. Labrum small, transverse, rounded anteriorly. Palps slender; ultimate palpomeres small, elongate, lanceolate. Antennal sockets separated by minute lamina. Antennae attaining to elytral two thirds, antennomeres 3-11 dentate, distinctly narrowing distally; antennomere 3 ca. 9 times longer than antennomere 2 and subequal in length to antennomere 4; antennomeres 3-11 with short sub-erect pubescence (Fig. 7).

Pronotum transverse, ca. 1.7 times as wide as long, with slightly widened anteriorly sides, almost straight basally and triangularly produced anteriorly, with narrow acute laterally produced posterior and conspicuous rounded anterior angles; median cell narrow, lanceolate, extending to 0.6 pronotal length; lateral carinae curved; anterior cells roundish. Scutellum subquadrate, slightly narrowing distally, emarginate at apex (Fig. 7).

Elytra long, 3.2 times longer than wide at humeri, parallel-sided, with equally developed primary costae; interstices with even rows of regular elongate cells; bottom of cells velvety and hairless; pubescence scarce, short and decumbent (Fig. 7).

Tibiae and femurs straight, relatively narrow; tarsi short, ca. 0.5 length of tibiae.

Aedeagus with conspicuously widened distally median lobe and elongate sclerotised inner sac process (Figs 8-9).

Female. Similar to male, differing by somewhat smaller eyes and shorter antennae.

Length: 4.7-6.0 mm. Width (humerally): $1.0-1.4 \mathrm{~mm}$.

ETYMOLOGY. The name of the new species is derived from the Latin for "with round areoles», alluding to the structure of its pronotum.

DIAGNOSIS. Xylobanus rotundeareolatus sp.n. may be differentiated from all the congeners by a combination of the wide pronotum with roundish anterior cells, elongate elytral cells and conspicuously widened distally median lobe of the aedeagus with elongate sclerotised inner sac process (Figs 7-9).

REMARKS. All specimens of the type series of Xylobanus rotundeareolatus sp.n. were collected at light, except for one collected by canopy fogging. 


\section{Xylobanus telefominensis Kazantsev, sp.n.} Figs 10-12

MATERIAL: Holotype, $\sigma^{7}$, Papua New Guinea, West Sepik prov., 2 km N Telefomin, 1500 m, 14.I.1989, R. Holyñski leg. (ICM).

DESCRIPTION. Male. Uniformly dark brown to black.

Vertex with two small deep round impressions behind antennal prominence. Eyes moderately large, interocular distance subequal in length to eye diameter. Labrum small, transverse, almost straight anteriorly and slightly emarginate medially. Palps slender; ultimate maxillary palpomeres small, elongate, almost parallel-sided, flattened and glabrous at truncate apex; ultimate labial palpomeres small, elongate, pointed and glabrous at apex. Antennal sockets narrowly separated. Antennae attaining to elytral two thirds, from antennomere 3 flabellate; antennomere 3 ca. 4.5 times longer than antennomere 2 and ca. 1.3 times longer than antennomere 4; flabella of antennomere $3 \mathrm{ca} .1 .7$ times longer than same antennomere, flabella of antennomere 4 ca. 2.5 times longer than same antennomere; antennomeres 3-11 with short sub-erect pubescence (Fig. 10).

Pronotum transverse, ca. 1.3 times as wide as long, slightly narrowing anteriorly, bisinuate basally, with prominent acute posterior and conspicuous blunt anterior angles; median cell noticeably widening distally, extending to 0.7 pronotal length; lateral carinae almost straight; anterior cells elongate, formed by straight anteriorly carinae. Scutellum subquadrate, slightly narrowed distally, greatly incised at apex (Fig. 10).

Elytra long, 3.7 times longer than wide at humeri, parallelsided, with equally developed primary costae; interstices with even rows of regular subquadrate cells; bottom of cells velvety and hairless; pubescence short and decumbent (Fig. 10).
Tibiae and femurs straight, narrow; tarsi short, ca. 0.6 length of tibiae.

Aedeagus with narrow (in lateral view) median lobe, with constricted apex (Figs 11-12).

Female. Unknown.

Length: $6.2 \mathrm{~mm}$. Width (humerally): $1.3 \mathrm{~mm}$.

ETYMOLOGY. The new species is named after "Telefomin", the locality where its type specimen was collected.

DIAGNOSIS. Xylobanus telefominensis sp.n. is quite similar to $X$. baitetaensis sp.n., but may be separated by the distinctly narrower median lobe of the aedeagus, with nonhooked apex (Figs 11-12); it may also be distinguished from both $X$. baitetaensis sp.n. and $X$. monilis by the much longer antennal flabellae (Fig. 10).

\section{Xylobanus waigeoensis Kazantsev, sp.n.}

Figs $13-15$

MATERIAL: Holotype, $\sigma^{7}$, E Indonesia, Raja Ampat, Waigeo Island, 2-3 km W Waisai, $00^{\circ} 25^{\prime} 40^{\prime \prime} \mathrm{S}, 130^{\circ} 47^{\prime} 36^{\prime \prime} \mathrm{E}$, ca. $70 \mathrm{~m}$, secondary lowland rainforest on limestone, MV light, 16-17.II.2012, D. Telnov leg. (NME); paratypes, $3 \sigma^{7} \sigma^{7}$ and ${ }^{\circ}$, same label; $\sigma^{7}, \mathrm{E}$ Indonesia, Raja Ampat, Waigeo Island, $3 \mathrm{~km}$ W Waisai, $00^{\circ} 26^{\prime} 04^{\prime \prime} \mathrm{S}$, $130^{\circ} 47^{\prime} 41^{\prime \prime} \mathrm{E}, 40-50 \mathrm{~m}$, secondary lowland rainforest on limestone and clearing, MV light, 18.II.2012, D. Telnov leg. (ICM and NME).

DESCRIPTION. Male. Dark brown to black; pedicel and base of scapus yellowish brown; pronotal margins and carinae light brown.

Vertex with conspicuous transverse impression behind antennal prominence. Eyes relatively small, interocular distance ca. 1.1 eye diameter. Labrum small, transverse, rounded anteriorly. Palps slender; ultimate maxillary palpomeres small, elongate, almost parallel-sided, flattened and glabrous at obliquely truncate apex; ultimate labial palpomeres small, elongate, point-
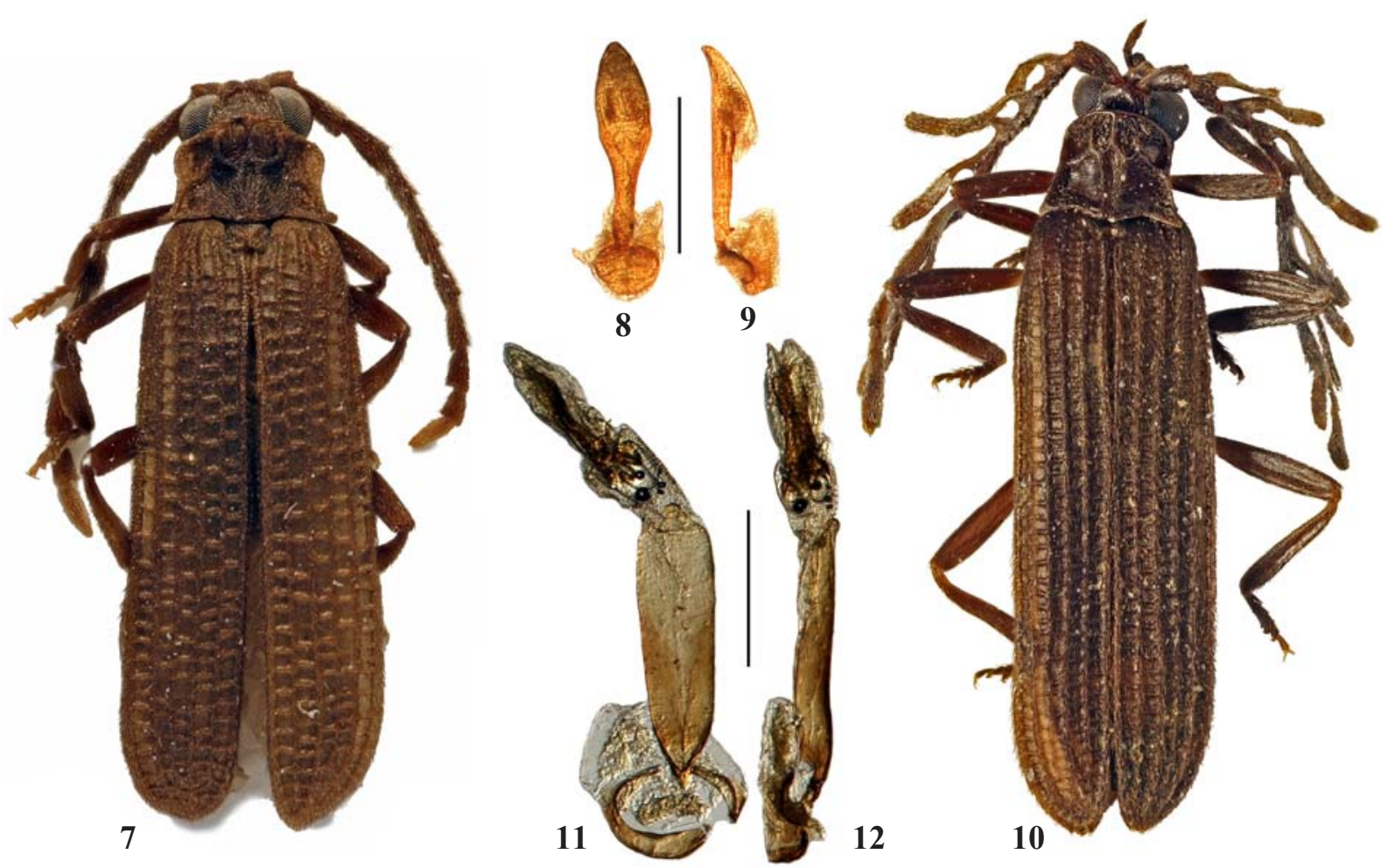

Figs 7-12. General view and aedeagi of Xylobanus, holotypes, males: 7-9 - X. rotundeareolatus sp.n.; 10-12 - X. telefominensis sp.n.; 7, 10 - general view; 8-9, 11-12 - aedeagi; 7-8, 10-11 - dorsally; 9, 12 - laterally. Scales: $0.5 \mathrm{~mm}$.

Рис. 7-12. Общий вид и эдеагусы Xylobanus, голотипы, самцы: 7-9 - X. rotundeareolatus sp.n.; 10-12 - X. telefominensis sp.n.; 7, 10 - общий вид; 8-9, 11-12 - эдеагусы; 7-8, 10-11 - сверху; 9, 12 - сбоку. Масштабные линейки: 0.5 мм. 
ed and glabrous at apex. Antennal sockets narrowly separated. Antennae attaining to elytral two thirds, from antennomere 3 flabellate; antennomere $3 \mathrm{ca} .10$ times longer than antennomere 2 and 1.2 times longer than antennomere 4; flabella of antennomere subequal in length to same antennomere, flabella of antennomere 4 ca. 1.4 times longer than same antennomere; antennomeres 3-11 with short erect pubescence (Fig. 13).

Pronotum transverse, ca. 1.3 times as wide as long, with almost parallel sides, bisinuate basally, with small acute posterior and conspicuous blunt anterior angles; lateral carinae almost straight; median cell narrow, extending to 0.7 pronotal length; anterior cells trapezoidal, formed by straight anteriorly carinae and diverging anteriorly. Scutellum subquadrate, narrowing distally, deeply incised at apex (Fig. 13).

Elytra long, 3.2 times longer than wide at humeri, parallel-sided, with equally developed primary costae; interstices with even rows of regular subquadrate cells; bottom of cells velvety and hairless; pubescence along costae short and decumbent (Fig. 13).

Tibiae and femurs straight, relatively narrow; tarsi short, ca. 0.55 length of tibiae.

Aedeagus with mostly parallel-sided and hooked at apex median lobe; inner sac with two pairs of small curved elongate hooks in proximal and distal parts (Figs 14-15).
Female. Similar to male, but eyes smaller and antennae just dentate.

Length: 4.6-5.2 mm. Width (humerally): $1.1-1.2 \mathrm{~mm}$.

ETYMOLOGY. The new species is named after the island of Waigeo, off the northwestern coast of New Guinea, where its type series was collected.

DIAGNOSIS. Xylobanus waigeoensis sp.n. is apparently close to $X$. baitetaensis sp.n., distinguishable by the distinctly more narrow at base and wider at apex and more hooked median lobe of the aedeagus (Figs 14-15). It may be separated from the also similar X. monilis by the broader median lobe of the aedeagus and longer antennal flabellae (Fig. 13).

\section{Xylobanus culex Kazantsev, sp.n.}

Figs 16-18

MATERIAL: Holotype, $\sigma^{7}$, Indonesia: Irian Jaya, Nabire area, road Nabire-Ilaga, km 62, 330.936'S, 13541.945'E, 250 m, KL UWS, X.1997, B. Balke leg. (NME).

DESCRIPTION. Male. Dark brown to black; palps, except ultimate palpomere, yellowish.

Vertex with deep transverse impression behind antennal prominence. Eyes relatively small, interocular distance ca. 1.6 times greater than eye diameter. Labrum small, transverse, rounded anteriorly. Palps slender; ultimate palpomeres

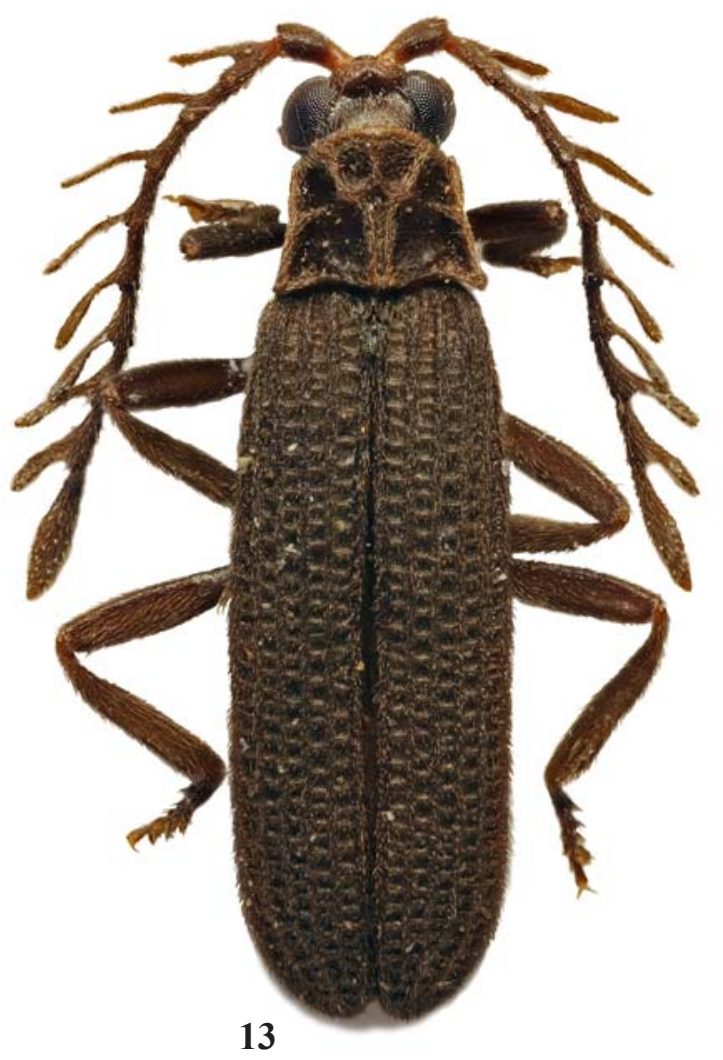

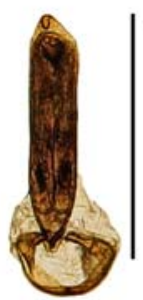

14

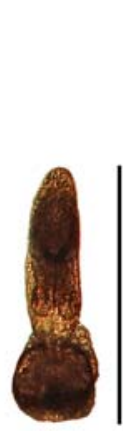

17

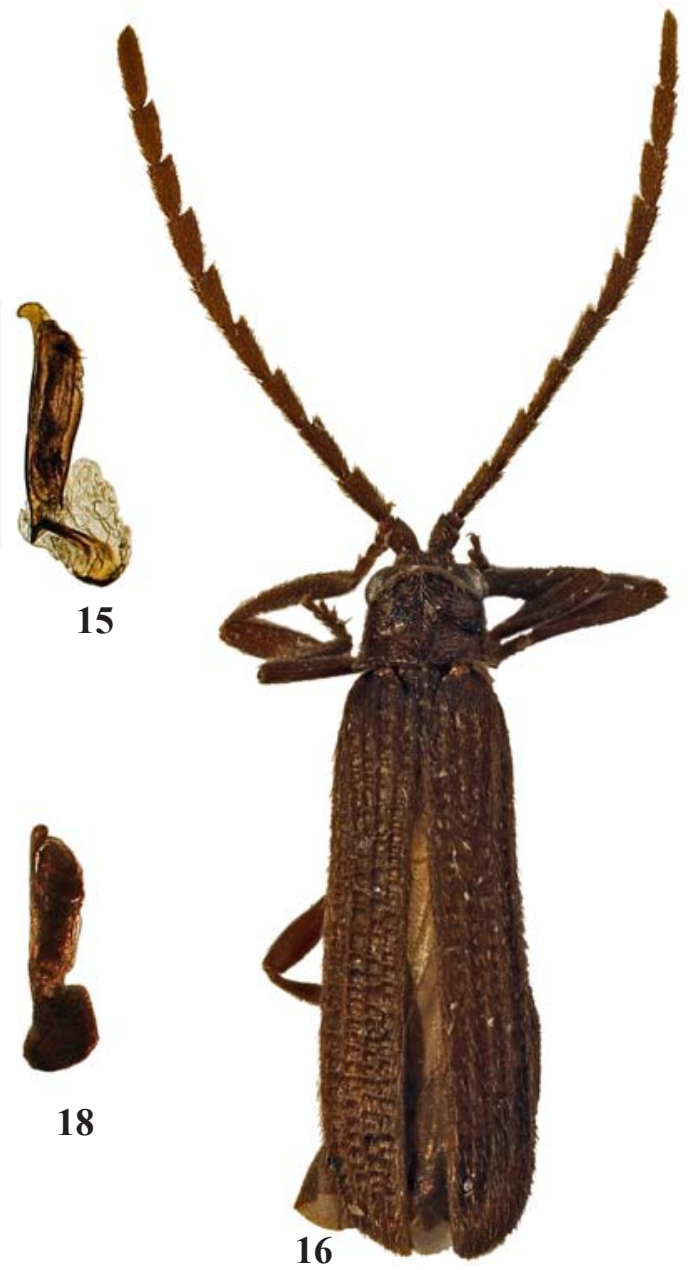

Figs 13-18. General view and aedeagi of Xylobanus, holotypes, males: 13-15 - X. waigeoensis sp.n.; 16-18 - X. culex sp.n.; 13, $16-$ general view; 14-15, 17-18 - aedeagi; 13-14, 16-17- dorsally; 15, 18 - laterally. Scales: $0.5 \mathrm{~mm}$.

Рис. 13-18. Общий вид и эдеагусы Xylobanus, голотипы, самцы: 13-15 - X. waigeoensis sp.n.; 16-18 - X. culex sp.n.; 13, 16 общий вид; 14-15, 17-18 - эдеагусы; 13-14, 16-17- сверху; 15, 18 - сбоку. Масштабные линейки: 0.5 мм. 
small, elongate, almost parallel-sided, flattened apex. Antennal sockets separated by minute lamina. Antennae attaining to elytral three fourths, narrow, slightly dentate; antennomere $3 \mathrm{ca} .5$ times longer than antennomere 2 and 1.2 times shorter than antennomere 4; antennomeres 3-11 with short erect pubescence (Fig. 16).

Pronotum transverse, ca. 1.4 times as wide as long, slightly narrowing anteriorly, feebly bisinuate basally, with small acute posterior and rounded anterior angles; lateral carinae, developed, straight; median cell diamond-shaped, extending to 0.8 pronotal length; anterior cells sub-quadrate, formed by straight anteriorly carinae. Scutellum subquadrate, narrowing distally, incised at apex (Fig. 16).

Elytra long, 4.3 times longer than wide at humeri, parallel-sided, with stout fourth and greatly reduced (present in proximal fifth only) third primary costae; interstices with regular, mostly transverse cells; bottom of cells velvety; pubescence scarce, short and sub-erect (Fig. 16).

Legs long; tibiae and femurs straight, relatively narrow; tarsi moderately short, ca. 0.6 length of tibiae.
Aedeagus with proximally broad median lobe, prominently incised in distal half, with sclerotised roundish inner sac process (Figs 17-18).

Female. Unknown.

Length: $3.4 \mathrm{~mm}$. Width (humerally): $0.7 \mathrm{~mm}$.

ETYMOLOGY. The name of the new species is derived from the Latin for "mosquito", alluding to its small size.

DIAGNOSIS. Xylobanus culex sp.n. is readily distinguishable from all other Xylobanus species by the greatly reduced third primary elytral costa (Fig. 16) and prominently incised in distal half median lobe of the aedeagus, with sclerotised roundish inner sac process (Figs 17-18).

\section{Xylobanus fakfakensis Kazantsev, sp.n.}

Figs 19-21

MATERIAL: Holotype, $0^{7}$, E Indonesia, West Papua, Fak-Fak peninsula, 5-7 km N Fak-Fak, 12-14 km NW Gamtu vill., 0253' $26^{\prime \prime} \mathrm{S}, 132^{\circ} 18^{\prime} 22^{\prime \prime} \mathrm{E}, 300-400 \mathrm{~m}$, primeval lowland rainforest on limestone, 23.X.2010, D. Telnov leg. (NME); paratype, OT, E Indo-

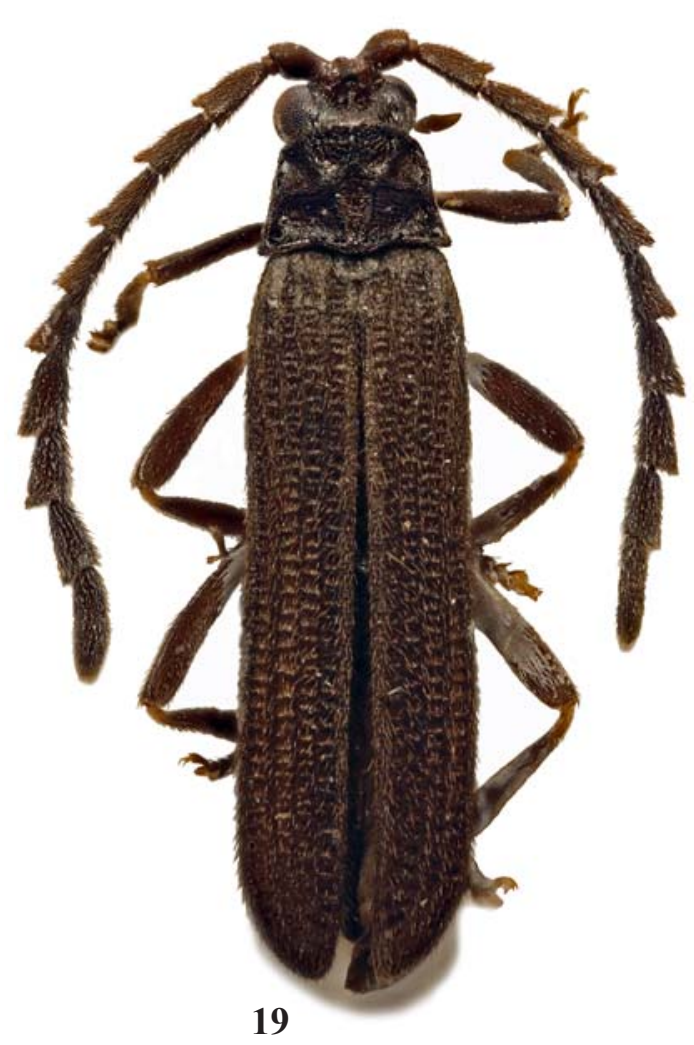

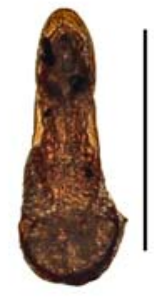

20

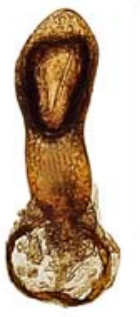

23

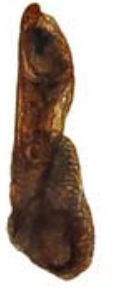

21

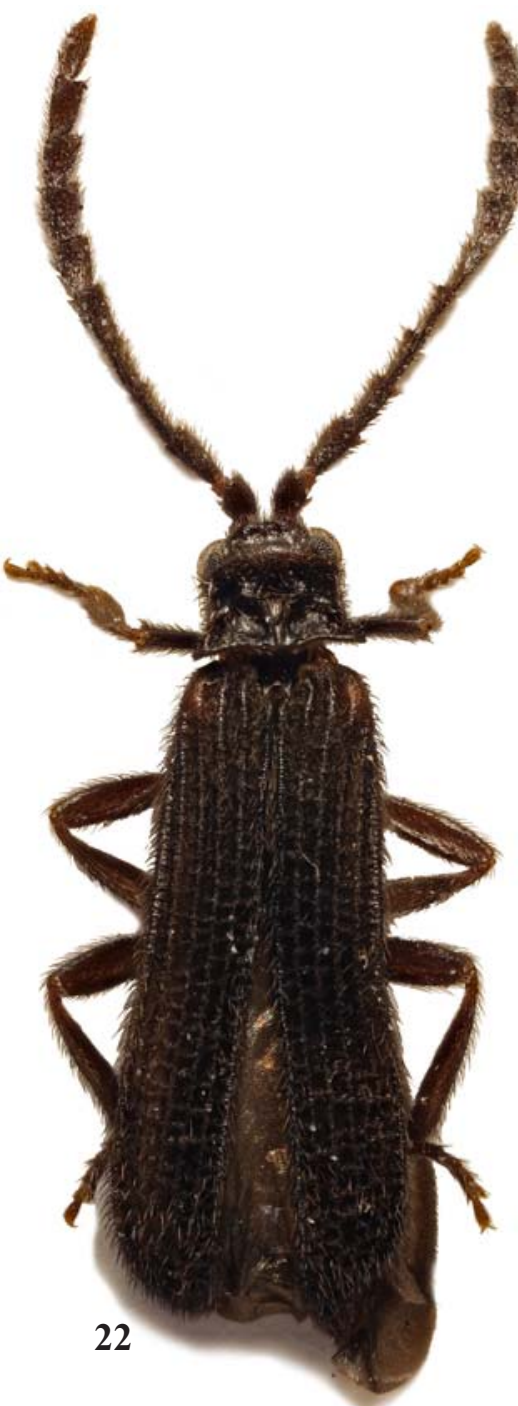

Figs 19-24. General view and aedeagi of Xylobanus and Xylobanomoprhus, holotypes, males: 19-21 - Xylobanus fakfakensis sp.n.; 22-24 - Xylobanomoprhus triton sp.n.; 19, 22 - general view; 20-21, 23-24 - aedeagi; 19-20, 22-23 - dorsally; 21, 24 - laterally. Scales: $0.5 \mathrm{~mm}$.

Рис. 19-24. Общий вид и эдеагусы Xylobanus и Xylobanomoprhus, голотипы, самцы: 19-21 - Xylobanus fakfakensis sp.n.; 22 24 - Xylobanomoprhus triton sp.n.; 19, 22 - общий вид; 20-21, 23-24 - эдеагусы; 19-20, 22-23 - сверху; 21, 24 - сбоку. Масштабные линейки: 0.5 мм. 
nesia, Raja Ampat, Missool Island (central), upstream Gam River, 12-14 km NW Gamtu vill., 01 ${ }^{\circ} 57^{\prime} 50^{\prime \prime} \mathrm{S}, 130^{\circ} 11^{\prime} 09^{\prime \prime} \mathrm{E}, 70-350 \mathrm{~m}$ primeval lowland rainforest, limestone creek valley, Malaise trap, 4-6.II.2012, D. Telnov leg. (ICM).

DESCRIPTION. Male. Dark brown to black; palps, except ultimate palpomere, yellowish.

Vertex with deep round impression behind antennal prominence. Eyes relatively small, interocular distance ca. 1.2 times greater than eye diameter. Labrum small, transverse, rounded anteriorly. Palps slender; ultimate palpomeres small, elongate, somewhat widened distally, flattened and obliquely truncate at apex. Antennal sockets separated by minute lamina. Antennae attaining to elytral four fifths, not tapering distally, dentate; antennomere 3 ca. 6 times longer than antennomere 2 and subequal in length to antennomere 4 antennomeres 3-11 with short erect pubescence (Fig. 19).

Pronotum transverse, ca. 1.5 times as wide as long, slightly narrowing anteriorly, bisinuate basally, with small acute posterior and rounded anterior angles; lateral carinae developed, slightly curved; median cell diamond-shaped, extending to 0.75 pronotal length; anterior cells diverging anteriorly, formed by straight anteriorly carinae. Scutellum subquadrate, parallelsided, slightly emarginate at apex (Fig. 19).

Elytra long, 3.5 times longer than wide at humeri, parallel-sided, with stout fourth and greatly reduced (present in proximal fourth only) third primary costae; interstices with regular transverse cells; bottom of cells velvety; pubescence scarce, short and sub-erect (Fig. 19).

Legs long; tibiae and femurs straight, relatively narrow.

Aedeagus with proximally broad median lobe, prominently incised in distal half, with sclerotised roundish inner sac process (Figs 20-21).

Female. Unknown.

Length: 4.2-4.4 mm. Width (humerally): $0.8-0.9 \mathrm{~mm}$.

ETYMOLOGY. The new species is named after Fak-Fak peninsula, in western New Guinea, where its type series was collected.

DIAGNOSIS. Xylobanus fakfakensis sp.n. is quite similar to $X$. culex sp.n., both externally and in the structure of the male genitalia, but may be differentiated by the greater size, more regular elytral reticulation and wider and more dentate antennomeres (Fig. 19).

\section{Xylobanomorphus Kleine, 1935}

Xylobanomorphus Kleine, 1935: 316

type species: Xylobanomorphus transformis Kleine, 1935: 316 (by monotypy).

\section{Xylobanomorphus triton Kazantsev, sp.n.} Figs 22-24

MATERIAL: Holotype, ○’, E Indonesia, West Papua, S Bird's Neck, 47 km E Kaimana, Triton Bay, env. vill. Kamaka (former Wanka), $03^{\circ} 46^{\prime} 42^{\prime \prime} \mathrm{S}, 134^{\circ} 10^{\prime} 24^{\prime \prime} \mathrm{E}, 50-130 \mathrm{~m}$, secondary rainforest on limestone and clearings, 10.IX.2010, D. Telnov leg. (NME); paratypes, $\sigma^{7}$, E Indonesia, West Papua, S Bird's Neck, 47 km E Kaimana, Triton Bay, env. vill. Kamaka (former Wanka), 03 ${ }^{\circ} 46^{\prime} 42^{\prime \prime} \mathrm{S}$, $134^{\circ} 10^{\prime} 24^{\prime \prime} \mathrm{E}, 50 \mathrm{~m}$, edge of primeval lowland rainforest, white light, 10.IX.2010, D. Telnov leg.; $2 \sigma^{\top} \sigma^{\top}$, E Indonesia, West Papua, S Bird's Neck, $40 \mathrm{~km}$ E Kaimana, Triton Bay, env. Lobo vill., $03^{\circ}$ $45^{\prime} 33^{\prime \prime} \mathrm{S}, 134^{\circ} 06^{\prime} 11^{\prime \prime} \mathrm{E}, 15-150 \mathrm{~m}$, secondary and primeval rainforest, Malaise trap, 11-17.IX.2010, D. Telnov leg.; ऽ', E Indonesia, Raja Ampat, Missool Island (central), upstream Gam River, 12-14 km NW Gamtu vill., 01 $57^{\prime} 50^{\prime \prime} \mathrm{S}, 130^{\circ} 11^{\prime} 09^{\prime \prime} \mathrm{E}, 70-350 \mathrm{~m}$, primeval lowland rainforest, limestone creek valley, Malaise trap, 4-6. II.2012, D. Telnov leg.; ণ , E Indonesia, Raja Ampat, Waigeo Island, $3 \mathrm{~km} \mathrm{~W}$ Waisai, $00^{\circ} 26^{\prime} 04^{\prime \prime} \mathrm{S}, 130^{\circ} 47^{\prime} 41^{\prime \prime} \mathrm{E}, 40-50 \mathrm{~m}$, secondary lowland rainforest on limestone and clearing, MV light, 18 II.2012, D. Telnov leg. (ICM and NME)
DESCRIPTION. Male. Dark brown to black; pedicel and humeral spot light brown.

Vertex with transverse impression behind antennal prominence. Eyes relatively small, interocular distance ca. 2 times greater than eye diameter. Labrum small, transverse, rounded anteriorly, almost completely hidden inside oral cavity. Palps slender; ultimate palpomeres small, elongate, almost parallel-sided, flattened and glabrous at apex. Antennal sockets separated by minute lamina. Antennae attaining to elytral three fifths, flattened, slightly dentate; antennomere 3 ca. 5.5 times longer than antennomere 2 and 1.2 times longer than antennomere 4; antennomeres 3-11 with relatively long erect pubescence (Fig. 22)

Pronotum transverse, ca. 1.6 times as wide as long, with almost parallel sides, bisinuate basally, with small acute posterior and inconspicuous blunt anterior angles; median cell diamond-shaped, reaching anterior margin; lateral carinae developed, slightly curved; anterior cells of irregular shape, antero-lateral carinae straight, reaching anterior margin. Scutellum subquadrate, parallel-sided, incised at apex (Fig. 22).

Elytra long, 4.3 times longer than wide at humeri, parallel-sided, with equally developed primary costae; interstices with even rows of irregular mostly elongate cells; bottom of cells velvety and hairless; pubescence relatively long and erect (Fig. 22).

Tibiae and femurs straight, relatively narrow, with relatively long and erect pubescence; tarsi ca. 0.5 length of tibiae, narrow; tarsomeres 1-3 without plantar pads.

Aedeagus with proximally broad median lobe and ringshaped inner sack distal structure (Figs 23-24).

Female. Unknown.

Length: 4.0-4.8 mm. Width (humerally): 0.9-1.1 mm.

ETYMOLOGY. The new species is named after Triton Bay, in western New Guinea, where its type series was collected.

DIAGNOSIS. Xylobanomorphus triton sp.n. is distinguishable from the similar X. balkei Kazantsev, 2010 by the uniformly black legs and proximally broad median lobe of the aedeagus (Figs 22-24).

\section{Malacolycus Kleine, 1943}

Malacolycus Kleine, 1943: 151.

type species: Malacolycus paululus Kleine, 1943: 151 (by monotypy).

\section{Malacolycus lacius Kazantsev, sp.n.} Figs 25-27

MATERIAL: Holotype, $\sigma^{7}$, Indonesia: Irian Jaya, Habbema Lake env., $04^{\circ} 8^{\prime} \mathrm{S}, 138^{\circ} 45.2^{\prime} \mathrm{E}, 3200$ m, 16.II.2002, A. Dexter leg. (ICM).

DESCRIPTION. Male. Dark brown to black; palps, except ultimate palpomere, pronotum, except at disk, and elytra yellowish grey.

Vertex with a pair of narrow longitudinal protuberances behind antennal prominence. Eyes moderately large, interocular distance subequal in length to eye diameter. Labrum small, transverse, rounded anteriorly, attached to epistoma. Palps slender; ultimate palpomeres small, elongate, widened distally, flattened and glabrous at obliquely truncate apex. Antennal sockets separated by minute lamina. Antennae attaining to elytral two thirds, narrow, slightly flattened, slightly dentate; antennomere 3 ca. 13 times longer than antennomere 2 and 1.1 times longer than antennomere 4; antennomeres 3-11 with relatively long erect pubescence (Fig. 25).

Pronotum transverse, ca. 1.4 times as wide as long, narrowing anteriorly, bisinuate basally, semicircular anteriorly; with long acute posterior and inconspicuous anterior 
angles; median cell oval, narrow, extending to 0.7 pronotal length and connected to pronotal margin by median keel; lateral and antero-lateral carinae absent. Scutellum subquadrate, narrowing distally, incised at apex (Fig. 25).

Elytra long, 8 times longer than pronotum and 4.4 times longer than wide at humeri, slightly widening distally, with primary costa 2 distinctly stouter, especially distally; interstices $1-2$ with one row of irregular subquadrate to elongate cells in proximal three fourths and double row in distal fourth; interstices 3-4 with one row of irregular subquadrate to elongate cells; interstice 5 with two rows of irregular cells; bottom of cells velvety and hairless; pubescence mostly along costae, very short and decumbent (Fig. 25).

Legs long and slender; tibiae and femurs straight, narrow; tarsi 0.55 length of tibiae; tarsomeres 1-2 with apical plantar pads.
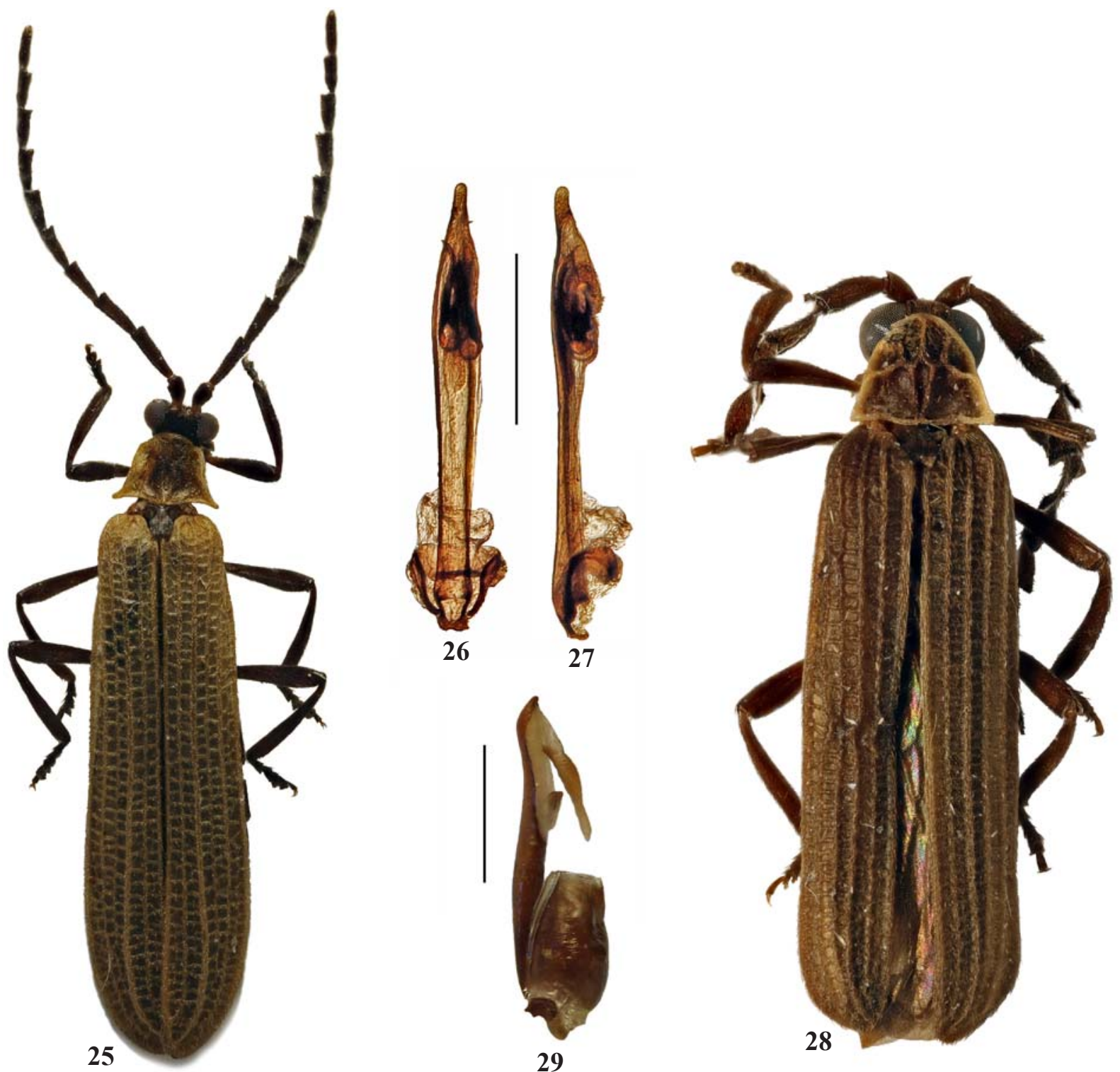

29
Aedeagus with narrow elongate, slightly widened distally and constricted at apex median lobe; inner sac with a pair of curved elongate asymmetric hooks in distal part (Figs 26-27).

Female. Unknown.

Length: $7.8 \mathrm{~mm}$. Width (humerally): $1.45 \mathrm{~mm}$.

ETYMOLOGY. The name of the new species is derived from "lacus", the Latin for "lake" alluding to the locality the type specimen was collected in.

DIAGNOSIS. Malacolycus lacius sp.n. may be differentiated from M. paululus Kleine, 1943, the type species and the only other known member of the genus, by the coloration, somewhat less elongate cells of elytral reticulation and narrow elongate median lobe of the aedeagus (Figs 25-27).

Figs 25-29. General view and aedeagi of Malacolycus and Mimoxylobanus, holotypes, males: 25-27 — Malacolycus lacius sp.n.; 28-29 Mimoxylobanus nubilus sp.n.; 25, 28 - general view; 26-27, 29 - aedeagi; 25-26, 28 - dorsally; 27, 29 - laterally. Scales: $0.5 \mathrm{~mm}$.

Рис. 25-29. Общий вид и эдеагусы Malacolycus и Mimoxylobanus, голотипы, самцы: 25-27 — Malacolycus lacius sp.n.; 28-29 Mimoxylobanus nubilus sp.n.; 25, 28 - общий вид; 26-27, 29 - эдеагусы; 25-26, 28 - сверху; 27, 29 - сбоку. Масштабные линейки: 0.5 мм. 
Mimoxylobanus Pic, 1921

Mimoxylobanus Pic, 1921: 11.

type species: Mimoxylobanus angustatus Pic, 1921: 11 (by monotypy).

\section{Mimoxylobanus nubilus Kazantsev, sp.n.}

Figs 28-29

MATERIAL: Holotype, $\sigma^{7}$, Papua New Guinea, Madang prov., Baiteta, light, 23.III.1993, O. Missa leg. (IRCN); paratype, O', Papua New Guinea, Madang prov., Baiteta, light, 18.III.1993, O. Missa leg. (ICM).

DESCRIPTION. Male. Dark brown; pronotal margins and carinae, except at disk, yellowish grey.

Head anteriorly with short rostrum. Vertex shining, finely punctate, with two round impressions behind antennal prominence. Eyes large, interocular distance ca. 1.5 times shorter than eye diameter. Labrum about as long as wide, narrowed and slightly emarginate anteriorly. Ultimate maxillary and labial palpomeres slender and elongate, pointed and glabrous distally. Antennal sockets separated by minute lamina. Antennae flattened, relatively narrow, slightly dentate, attaining to elytral two thirds; antennomere 3 ca. 10 times longer than antennomere 2 and ca. 1.3 times longer than antennomere 4; antennomeres 3-11 with short sub-erect pubescence (Fig. 28).

Pronotum ca. 1.15 times wider than long, trapezoidal, strongly produced anteriorly and slightly bisinuate at base, with acute posterior angles; all carinae well developed and straight, except lateral carinae which are noticeably curved. Scutellum subquadrate, oval, incised at apex (Fig. 28).

Elytra long, 3.3 times longer than wide at humeri, parallel-sided, with four equally developed primary costae; interstices with even rows of regular transverse cells; pubescence short and decumbent, bottom of cells finely alveolate, without hairs (Fig. 28)

Aedeagus with slightly widened and bent before apex median lobe; inner sac with elongate, backward directed process; parameres forming a tube open distally, conspicuously sclerotized and about as long as half of median lobe; phallobase small and narrow, circular (Fig. 29).

Female. Unknown.

Length: $6.0-6.2 \mathrm{~mm}$. Width (humerally): $1.4-1.5 \mathrm{~mm}$.

ETYMOLOGY. The name of the new species is derived from the Latin from "overcast" alluding to the coloration of its pronotum.

DIAGNOSIS. Mimoxylobanus nubilus sp.n. is easily separable from $M$. angustatus Pic, 1921, the type species and the only other known member of the genus, by the more narrowed anteriorly pronotum, pointed and glabrous distally palpomeres, as well as somewhat wider median lobe and distinctly longer parameres of the aedeagus (Figs 28-29).

REMARKS. The sclerotised parameres of the aedeagus, as in Mimoxylobanus nubilus sp.n. (and, presumably, in $M$. angustatus), are reported only in Leptotrichalus Kleine, 1925 or Lobatang, Bocak, 1999 [Bocak, 2002] that belong to another lineage of mertiorrhynchines.

\section{Xylothrix Kazantsev gen.n.}

Type species: Xylothrix athrix Kazantsev, sp.n.

DESCRIPTION. Male. Alate, slender, elongate. Head transverse, conspicuously impressed between eyes behind antennal prominence, slightly narrowed behind eyes. Fastigium acute. Eyes relatively large, spherical. Labrum small, rounded anteriorly. Mandibles slender, circularly rounded. Maxillary palps slender, 4-segmented, with ultimate palpomere elongate, pointed distally. Labial palps 3-segmented, ultimate palpomere elongate, pointed distally. Antennal prom- inence moderately bulging; antennal sockets separated by narrow lamina. Antenna 11-segmented, long, from antennomere 3 flabellate, flabellae arising from bases of antennomeres; antennomere 3 considerably longer than antennomere 2 and slightly longer than antennomere 4; antennomeres 3-11 with short erect pubescence (Fig. 30).

Pronotum moderately transverse, slightly more narrow than elytra, with prominent posterior and noticeable anterior angles; median areole diamond-shaped, extending over pronotal middle; antero-lateral and lateral carinae straight and conspicuous. Elytra parallel-sided, with four fully and equally developed primary costae; interstices with one row of small, mostly transverse cells; elytral pubescence short and scarce, not concealing elytral reticulation (Fig. 30).

Legs moderately long; trochanters considerably longer than wide, narrow, considerably shorter than femurs, connected to femora distally; femurs and tibiae straight, narrow, slightly flattened, tibiae slightly shorter than femurs, tibial spurs absent; tarsomeres narrow; tarsomere 1 without plantar pad, tarsomeres 2 and 3 with apical plantar pad; all claws simple. Proctiger medially attached to paraproct; paraproct with complete median suture; ultimate ventrite elliptical, with symmetric, moderately long and rather broad spiculum gastrale.

Aedeagus symmetric, with elongate dorsal process of median lobe; inner sac with a pair of roundish spines and a pair of elongate slightly curved lobes and disk-like semi-sclerotised apical process; phallobase anuliform, narrow (Figs 31-32).

Female. Similar to male, but antennal flabellae shorter, eyes somewhat smaller (Fig. 33). Spiculum ventrale absent. Valvifers very narrow and about as long as coxites; coxites elongate, narrow, subfused proximally; styli elongate, narrow (Fig. 34).

ETYMOLOGY. The name of the new genus is derived from the names of the genera Xylobanus Waterhouse, 1878 and Carathrix Kleine, 1926, a junior synonym of Pseudodontocerus Pic, 1921, alluding to the similarity of the type species in its elytral structure to Xylobanus and in its antennal structure to Carathrix. Gender feminine.

DIAGNOSIS. Xylothrix gen.n. is easily differentiated from all other Metriorrhynchini with one row of cells between four primary elytral costae (except Xylobanomimus) by the flabellate (both male and female) antennomeres, with flabellae stemming from the bases of antennomeres (Fig. 30). At the same time it may be distinguished from Xylobanomimus by the widened ultimate maxillary palpomere, transverse cells of the elytral reticulation, distinct lateral and antero-lateral pronotal carinae and elongate dorsal process of median lobe of the aedeagus with elongate sclerotised distal portion of the inner sac (Figs 30-33). The structure of antennomeres, with flabellae stemming from the bases of antennomeres, and the elongate dorsal process of median lobe of the aedeagus with disk-shaped semi-sclerotised distal portion of the inner sac are hypothesized to be the autapomorphies of the new genus.

\section{Xylothrix athrix Kazantsev, sp.n.}

Figs 30-33

MATERIAL: Holotype, $\sigma^{\top}$, Papua New Guinea, Madang prov., Baiteta, 20.V.1996, O. Missa leg. (IRCN); paratypes, 9 , Papua New Guinea, Madang prov., Baiteta, light, 17.IV.1996, O. Missa leg.; and $16 \sigma^{\top} \sigma^{\top}$, same label, dates: 18.III.1993 (2 specimens), 24.III.1993, 20.IV.1993, 21.IV.1993 (2 specimens), 22.IV.1993, 1995, 16.IV.1996, 22.IV.1996, 29.IV.1996 (2 specimens), 30.IV.1996, 25.VI.1996, 3.VII.1996, 4.VII.1996 (ICM and IRCN). brown. 
Vertex with two small deep round impressions behind antennal prominence. Eyes large, interocular distance ca. 1.5 times greater than eye diameter. Labrum small, semicircular. Palps slender; ultimate palpomeres small, rounded, pointed and glabrous at apex. Antennal sockets separated by minute lamina. Antennae attaining to elytral three fourths, from antennomere 3 flabellate; antennomere 3 ca. 8 times longer than antennomere 2 and 1.3 times longer than antennomere 4 ; flabella of antennomere 3 subequal in length to same antennomere, flabella of antennomere $4 \mathrm{ca} .1 .8$ times longer than same antennomere; antennomeres 3-11 with short erect pubescence (Fig. 30).

Pronotum transverse, ca. 1.2 times as wide as long, slightly narrowing anteriorly, bisinuate basally, with small acute posterior and conspicuous blunt anterior angles; median cell moderately broad, extending to 0.75 pronotal length; lateral carinae straight; anterior cells diverging anteriorly, formed by straight antero-lateral carinae. Scutellum subquadrate, slightly narrowing distally, emarginate at apex (Fig. 30).

Elytra long, 3.7 times longer than wide at humeri, parallel-sided, with equally developed primary costae; interstices with even rows of regular transverse cells; bottom of cells velvety; pubescence mostly along costae, short and decumbent (Fig. 30).

Tibiae and femurs straight, relatively narrow; tarsi short, ca. 0.6 length of tibiae, narrow.
Aedeagus with slightly widened medially median lobe; inner sac distal process ca. 2 times shorter than median lobe (Figs 31-32).

Female. Similar to male, but antennal flabellae somewhat shorter, eyes smaller (Fig. 33). Valvifers narrow, mildly rounded, not connected medially, subequal in length to coxites; coxites straight; styli narrow, about 3 times shorter than coxites.

Length: 4.8-6.0 mm. Width (humerally): $1.2-1.3 \mathrm{~mm}$.

ETYMOLOGY. The name of the new species is derived from Carathrix, a junior synonym of Pseudodontocerus, alluding to the similarity of its antennal structure to that of the latter genus.

DIAGNOSIS. Xylothrix athrix sp.n. is similar in general appearance to Xylobanus baitetaensis sp.n., but can be readily separated by the generic characters.

\section{Xylothrix avicollis Kazantsev, sp.n.}

Figs 34-35

MATERIAL: Holotype, 9 , E Indonesia, West Papua, S Bird's

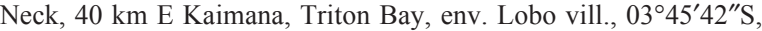
$134^{\circ} 05^{\prime} 40^{\prime \prime} \mathrm{E}, 130-140 \mathrm{~m}$, secondary rainforest on limestone, UV light, 15.IX.2010, D. Telnov leg. (NME); paratypes, + , same label; +, E Indonesia, West Papua, S Bird's Neck, 40 km E Kaimana, Triton Bay, env. Lobo vill., $03^{\circ} 45^{\prime} 33^{\prime \prime} \mathrm{S}, 134^{\circ} 06^{\prime} 11^{\prime \prime} \mathrm{E}, 15-150 \mathrm{~m}$, secondary and primeval rainforest on limestone, 11-12.IX.2010, D. Telnov leg. (ICM and NME).
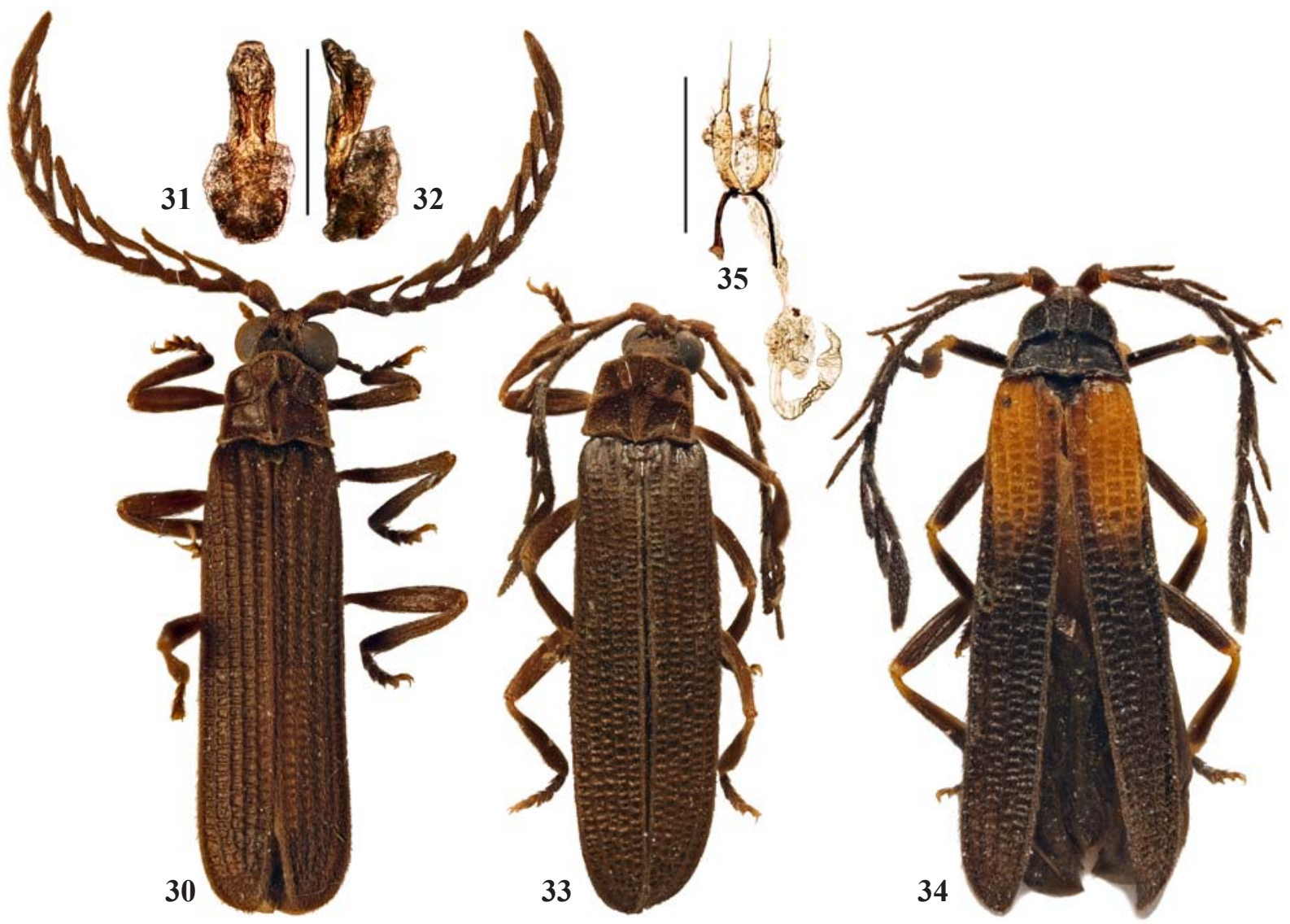

Figs 30-35. General view and copulatory organs of Xylothrix gen.n.: 30-33-X. athrix sp.n.; 34-35 - X. avicollis sp.n.; 30-32, 3435 - holotypes; 33 - paratype; 30-32 - male; 33-35 - females; 30, 33-34 - general view; 31-32 - aedeagi; 35 - female copulatory organ; 30-31, 33-35 - dorsally; 32 - laterally. Scales: $0.5 \mathrm{~mm}$.

Рис. 30-35. Общий вид и гениталии Xylothrix gen.n.: 30-33-X. athrix sp.n.; 34-35-X. avicollis sp.n.; 30-32, 34-35 — голотипы; 33 - паратип; 30-32 - самец; 33-35 - самки; 30, 33-34 - общий вид; 31-32 - эдеагусы; 35 — женские гениталии; 30-31, 3335 - сверху; 32 - сбоку. Масштабные линейки: 0.5 мм. 
DESCRIPTION. Female. Dark brown to black; pedicel, palpomeres, meso- and metaventrite, elytra in proximal third, trochanters, femurs proximally, knees and tibiae distally brownish orange.

Vertex with two conspicuous distant round impressions behind antennal prominence. Eyes small, interocular distance ca. 1.5 greater than eye diameter. Labrum small, transverse, rounded. Palps slender; ultimate maxillary palpomere small, elongate, conspicuously widening distally, flattened at apex; ultimate labial palpomere small, elongate, pointed and glabrous at apex. Antennal sockets separated by minute lamina. Antennae attaining to elytral three fourths, from antennomere 3 flabellate, flabellae attached to bases of antennomeres; antennomere $3 \mathrm{ca} .8$ times longer than antennomere 2 and 1.2 longer than antennomere 4; flabella of antennomere $3 \mathrm{ca}$. 1.2 times shorter than same antennomere, flabella of antennomere 4 ca. 1.1 times longer than same antennomere; antennomeres 3-11 with short erect pubescence (Fig. 34).

Pronotum transverse, ca. 1.5 times as wide as long, narrowing anteriorly, bisinuate basally, with prominent acute posterior and rounded anterior angles; median cell narrow, extending to 0.6 pronotal length; lateral carinae almost straight; anterior cells elongate, formed by straight anteriorly carinae. Scutellum transverse, triangular, feebly emarginate at apex (Fig. 34).

Elytra long, 3.9 times longer than wide at humeri, parallel-sided, with three equally developed primary costae, costa 3 present in proximal third; interstices with even rows of irregular transverse cells; bottom of cells velvety; pubescence along costae short and decumbent (Fig. 34).

Tibiae and femurs straight, narrow; tarsi short, ca. 0.45 length of tibiae, narrow.

Valvifers narrow, mildly rounded, abruptly widened at base, connected medially, slightly shorter than coxites; coxites slightly bent in proximal third, slightly widening distally; styli about 3 times shorter than coxites, with long apical bristle of setae (Fig. 35).

Male. Unknown.

Length: 4.7-6.0 mm. Width (humerally): $1.1-1.45 \mathrm{~mm}$.

ETYMOLOGY. The name of the new species is derived from the Latin for "Bird's Neck", in accordance with the locality where its type series was collected.

DIAGNOSIS. Xylothrix avicollis sp.n. may be easily differentiated from $X$. athrix sp.n., the only other known species of the genus, by the coloration, widened ultimate maxillary palpomere and greatly reduced third primary elytral costa (Fig. 34).

\section{Discussion}

The sclerotised parameres of the aedeagus, or the "sclerotised membrane of the phallobase" of Bocák [2002], present in Mimoxylobanus nubilus sp.n. (and, presumably, in $M$. angustatus) are reported only in few other mertiorrhynchines, such as Leptotrichalus Kleine, 1925 or Lobatang, Bocák, 1998. Although the absence of parameres is considered a homoplasy of the lineage [Bocák, 2002], their presence in M. nubilus sp.n. and in Leptotrichalus or Lobatang species seems to be yet another homoplasy, as these taxa are apparently little related.

The New Guinean species Xylobanus fakfakensis sp.n. and $X$. culex sp.n. are markedly different from all other Xylobanus species in having greatly reduced third primary elytral costa (Figs 16,19$)$ and prominently in- cised in distal half median lobe of the aedeagus, with sclerotised roundish inner sac process (Figs 17-18, 2021). Although the structure of their aedeagi is reminiscent of that of certain Xylobanomoprhus, e.g., X. longissimus Kazantsev, 2010 or X. balkei Kazantsev, 2010, other characters, such as the non-pointed distally palpomeres, shorter median pronotal cell, transverse cells of elytral reticulation, do not allow attributing them to the latter genus, which, in its turn is characterized by four fully developed primary elytral costae (e.g., Fig. 22).

Another example of the conspicuous reduction of the third primary elytral costa may be observed in Xylothrix avicollis sp.n. Reduction of primary elytral costae is often regarded as an important apomorphy and taxa possessing reduced costae are often separated at the genus level, e.g., Benibotarus Kono, 1932 in Erotini, Eniclases Waterhouse, 1879 or Marena Kazantsev, 2007 in Metriorrhynchini. However, in most cases such separation is supported by additional autapomorphies of the taxa. In case of Xylothrix avicollis sp.n., as well as in Xylobanus fakfakensis sp.n. and $X$. culex sp.n. not enough sound additional autapomorphies have been found. Therefore, the new species are placed in Xylothrix and Xylobanus, respectively, until their position is clarified when at least their males (in case of Xylothrix avicollis sp.n.) or females (in case of Xylobanus fakfakensis sp.n. and $X$. culex sp.n.) are discovered.

ACKNOWLEDGEMENTS. It is my pleasant duty to express gratitude to Dr. P. Grootaert (Institut Royal de Sciences naturelles de Belgique, Bruxelles), Dr. M. Hartmann (Naturkundemuseum, Erfurt), Dr. A. Kopetz (Krefeld, Germany) and Dr. D. Telnov (Entomological Society of Latvia, Riga), through whose courtesy I was able to study the Lycidae collections under their care. My sincere thanks are also due to Dr. R. Holyñski (Milanowek, Poland) for providing interesting material collected during his entomological expeditions to New Guinea.

\section{References}

Bocák L. 1997. A new species of the genus Eniclases (Coleoptera: Lycidae) // Acta Universitatis Palackianae Olomucensis, Biol. Vol.35. P.13-16.

Bocák L. 1999a. A new genus Oriomum from New Guinea (Coleoptera, Lycidae, Metriorrhynchini) // Entomologica Basiliensia. Vol.21. P.111-114.

Bocák L. 1999b. New taxa of the subtribe Hemiconderina (Coleoptera: Lycidae) from Indonesia and New Guinea // Entomologische Blätter. B.95. H.2/3. S.166-170.

Bocák L. 2001. Revision of the genus Diatrichalus Kleine from New Guinea (Coleoptera: Lycidae) // Stuttgarter Beiträge zur Natukunde (Serie A, Biologie). B.622. S.1-32.

Bocák L. 2002. Generic revision and phylogenetic analysis of the Metriorrhynchinae (Coleoptera: Lycidae) // European Journal of Entomology. Vol.99. P.315-351.

Bocák L., Bocáková M. 1991. Revision of the genus Eniclases Waterhouse, 1879 (Coleoptera, Lycidae, Metriorrhynchinae) // Mitteilungen der Münchner Entomologischen Gesellschaft. B.81. S.203-226.

Bocák L., Bocáková M. 1992. Revision of the genus Calochromus Guerin-Meneville (Coleoptera, Lycidae) from New Guinea and adjacent islands // Acta Entomologica Bohemoslovaca. Vol.89. P.301-308 
Bocáková M. 1997. Revision and phylogenetic analysis of the genus Melaneros Fairmaire, 1877 (Coleoptera, Lycidae) from New Guinea // Entomologica Basiliensia Vol.20. P.165-222.

Guérin-Méneville F.-E. 1833. Mémoire sur deux nouveaux genres de l'ordre des Coléoptères et descriptions des espèces qui les composent // Annales de la Société entomologique de France. Vol.2. P.155-160.

Kazantsev S.V. 2007. Marena gen.n., new Metriorrhynchini genus from New Guinea (Coleoptera: Lycidae) // Russian Entomological Journal. Vol.16. No.3. P.297-300.

Kazantsev S.V. 2010. New taxa of Papuan net-winged beetles (Lycidae, Coleoptera) // Latvijas Entomologs. Vol.48. P.92-100.

Kleine R. 1926a. Coleoptera. Lycidae // Nova Guinea. Résultats des Expéditions scientifiques à la Nouvelle Guinée. Vol.15. Leiden: E.J. Brill. P.91-195.

Kleine R. 1926b. I neue Brenthide und 2 neue Lyciden aus NeuGuinea // Nova Guinea. Résultats des Expéditions scientifiques à la Nouvelle Guinée. Vol.15. Leiden: E.J. Brill. P.409-410.
Kleine R. 1933. Pars 123: Lycidae. Coleopterorum Catalogus auspiciis et auxilio W. Junk editus a Schenkling. Berlin: W. Junk. 145 p.

Kleine R. 1935a. Fünf neue Lycidae vom Edie Creek, British Neu Guinea // Nova Guinea. Résultats des Expéditions scientifiques à la Nouvelle Guinée. Vol.17. Leiden: E.J. Brill. P.151-154.

Kleine R. 1935b. Bericht über die von Miss Cheesman in British Neu-Guinea gesammelten. Brenthiden und Lyciden // Nova Guinea. Résultats des Expéditions scientifiques à la Nouvelle Guinée. Vol.17. Leiden: E.J. Brill. P.309-321.

Kleine R. 1939. Neue Brenthiden und Lyciden die Miss Cheesman 1936 in Hollaendisch Neu Guinea gesammelt hat // Nova Guinea. Journal of Botany, Zoology, Anthropology, Ichnography, Geology and Palaeonthology of the Papuan Region. Vol.3. Leiden: E.J. Brill. P.106-112.

Riedel A. 2008. Three new species of Euops Schoenherrr from the forest canopy in Papua New Guinea (Coleoptera, Curuculionoidea, Attelabidae) // Mitteilungen der Münchner Entomologischen Gesellschaft. Bd.98. S.127-142. 